KHAZANAH, Vol. 7 No.2 Januari 2015

\title{
KOMBINASI EKSTRAK TEMU PUTIH (Curcuma zedoaria) DAN BAWANG PUTIH (Allium sativum L.) TERHADAP AKTIVITAS SEL LIMFOMA DENGAN METODE MTT $A S S A Y$
}

\author{
Istiqari Silma Arifah, Kharismatul Khasanah, Diny Lidy, Herianto \\ Pandapotan
}

\section{Jurusan Farmasi, Fakultas Matematika dan Ilmu Pengetahuan Alam, Universitas Islam Indonesia}

\section{RINGKASAN}

Tumor merupakan proses terjadinya pertumbuhan sel yang tidak beraturan dan tak terkontrol (abnormal). Tumor ini bisa bersifat kanker (malignant) atau non-kanker (jinak). Dengan dilakukan penelitan terhadap aktivitas sel lymphoma terhadap kombinasi ekstrak temu putih dan bawang putih menggunakan metode MTT Assay bertujuan untuk menguji keefektifan dari kombinasi ekstrak tersebut terhadap aktifitas sel lymphoma. Bawang putih (Allium sativum) memiliki senyawa organosulfur yang dapat menekanan proliferasi sel dengan menghalangi perkembangan siklus sel tanpa diikuti kerusakan sel disekitarnya. Sedangkan temu putih (Curcuma zedoaria) memiliki mekanisme anti kanker dengan menginduksi apoptosis dari sel kanker itu sendiri tanpa merusak sel lain disekitarnya. Kombinasi ekstrak tersebut diharapkan dapat member efek sinergi dalam penghambatan aktivitas tumor lymphoma. Serbuk simplisia dibuat dalam bentuk ekstrak dengan menggunakan metode maserasi dan menggunakan pelarut etanol $70 \%$. Maserat yang telah diperoleh akan disaring dan diuapkan dengan penguap vakum atau penguap tekanan rendah hingga diperoleh ekstrak kental. Ekstrak kental kemudian diujikan pada sel lymphoma dengan seri dosis $50: 50$ ( $500: 500 ; 250: 250 ; 125: 125 ; 62,5: 62,5$; 31,25:31,25; 15, 625 ; 15,625 ppm) yang telah dibiakkan pada media komplit di dalam mikroplate dan diberi reagen MTT Assay 0,5\%. Hal ini bertujuan untuk mengamati besarnya persen kematian sel (\%) dan kristal formazan yang terbentuk. Data hasil pengamatan yang diperoleh, dianalisis dengan menggunakan Elisa reader pada panjang gelombang $550 \mathrm{~nm}$.

Keyword : tumor, lymphoma, bawang putih (Allium sativum), temu putih (Curcuma zedoaria), MTT Assay 


\section{PENDAHULUAN}

\section{A. Latar Belakang Masalah}

Tumor dapat timbul karena adanya pertumbuhan sel yang tidak beraturan dan tak terkontrol (abnormal). Tumor dapat bersifat kanker (malignant) atau non-kanker jinak (National Cancer Institut,2006). Gen yang berperan utama dalam memicu tumor adalah proto-oncogenes dan tumor suppressor. Proto-oncogenes berperan dalam pertumbuhan sel tumor sedangkan tumor suppressor sebagai penghambat pertumbuhan tumor itu sendiri. Mekanisme kedua sel ini secara normal mencegah terjadinya pembelahan sel yang berlebihan. Dalam kondisi sel yang mengalami mutasi maka oncogenes akan mengalami pembelahan sel yang tidak terkendali tetapi gen tumor suppressor gagal menghambat pembelahannya (Kintzios, \& Barberaki, 2004).

Secara konvensional, penanggulangan tumor dilakukan melalui tindakan operasi, radiasi dan kemoterapi. Sebenarnya pengobatan tersebut belum dapat dikatakan baik karena memiliki beberapa efek samping lain yang tidak dikehendaki (Kintzios, \& Barberaki, 2004). Untuk mengantisipasi pengobatan yang memiliki efek samping dan biaya perawatan yang mahal maka manusia mulai mengembangkan pengobatan alternatif. Untuk mencegah dan mengurangi pertumbuhan dari sel kanker bukan sebagai terapi utama dari pengobatan kanker, diantaranya dengan pemakaian sediaan seperti herbal mahkota dewa, temu putih, bawang putih dan lain-lain. Sebagai terapi pendamping kanker, bawang putih yang sudah sering digunakan sebagai bumbu dapur ini memiliki kandungan antioksidan dan organosulfur yang dapat menginduksi terjadinya apoptosis sel kanker (Ranjani et al,2012).Bawang putih (Allium sativum) memiliki mekanisme yang terlibat dalam efek antikarsinogenik dengansenyawaorganosulfurnyayang mencakup penekanan proliferasi sel dengan menghalangi perkembangan siklus sel atau merangsang apoptosis sel kanker itu sendiri tanpa diikuti kerusakan sel disekitarnya (Ranjani et al,2012). Sedangkan temu putih (Curcuma zedoaria) memiliki mekanisme anti kanker dengan menginduksi apoptosis dari sel kanker itu sendiri tanpa merusak sel lain disekitarnya dan menghambat proliferasi sel kanker (Lakshmi et al,2011). Berdasarkan kebiasaan masyarakat tersebut maka dalam proposal ini akan dilakukan penelitian terkait "Kombinasi Ekstrak Temu Putih Dan Bawang Putih Terhadap Aktivitas Sel Limfoma dengan Menggunakan Metode MTT Assay. Hal ini dilakukan karena metode ini lebih mudah dan murah dilakukan dibandingkan dengan metode lainnya. 


\section{B. Rumusan Masalah}

Bagaimanakah pengaruh ekstrak temu putih dan bawang putih secara tunggal-tunggal dan kombinasi terhadap aktivitas sel limfoma (raji) dengan menggunakan metode MTT assay?

\section{TujuanProgram}

Mengetahui pengaruh ekstrak temu putih dan bawang putih secara tunggal-tunggal dan kombinasi terhadap aktivitas sel limfoma (raji) dengan menggunakan metode MTT assay..

\section{Luaran Yang Diharapkan}

Mengetahui aktivitas ekstrak temu putih (C. zedoaria) dan bawang putih (A. sativum $L$.) secara tunggal-tunggal dan kombinasi terhadap aktivitas sellimfomamenggunakanmetode MTT assay, sehingga diperoleh alternatif pengobatan herbal untuk kanker limfoma. Dapat dilanjutkan penelitian yang lebih mendalam lagi mengenai aktifitas antiproliferasi dari kedua ekstrak tersebut.

\section{E. Kegunaan Program}

Hasil penelitian ini diharapkan dapat digunakan sebagai informasi tentang tanaman herbal yang dapat menurunkan aktivitas tumor, sehingga dapat digunakan sebagai kombinasi dengan obat konvensional. Informasi tersebut diharapkan dapat menambah khasanah informasi obat alami yang dapat digunakan untuk pengembangan ilmu pengetahuan dibidang kesehatan.

\section{F. TINJAUAN PUSTAKA}

\section{Perkembangan Sel Tumor}

Tumor merupakan proses terjadinya pertumbuhan sel yang tidak beraturandan tak terkontrol (abnormal). Tumor ini bisa bersifat kanker (malignant) atau non-kanker (jinak). Jenis tumor malignant dapat tumbuh dimana saja, selain itu bisa menyebar ke jaringan tubuh lain disekitarnya melalui sistem limfatik atau aliran darah, biasanya setelah adanya pengangkatan tumor ada kemungkinan akan tumbuh kembali dan dapat menyebabkan kematian. Sedangkan tumor jinak hanya tumbuh disatu tempat tidak dapat menyebar ke jaringan lain disekitarnya, tumor ini jarang sekali menyebabkan kematian dan setelah adanya pengangkatan tumor tidak dapat tumbuh lagi (National Cancer Institut,2006).

Penyebab tumbuhnya tumor adalah adanya masalah dengan sistem kekebalan tubuh. Selain itu penyebab lain diantaranya tembakau, benzena dan bahan kimia lainnya, alkohol, lingkungan yang beracun, radiasi sinar UV dan lainnya, mutasi genetik, obesitas, virus dan agen karsinogenik lainnya (National Cancer Institut,2006). Gejala dan tanda pada tumor umumnya terjadi seperti panas dingin, kelelahan, demam, kehilangan nafsu makan, rasa tidak enak, keringat malam dan penurunan berat badan. Namun beberapa jenis tumor tidak menunjukkan gejala dan tanda 
tapi langsung diketahui saat sudah mencapai stadium lanjut (National Cancer Institut,2006).

\section{Temu putih (Curcuma zedoaria)}

Temu putih (C. zedoaria) yang merupakan salah satu tanaman dari keluarga temu-temuan (Zingiberaceae). Tanaman ini telah banyak digunakan sebagai salah satu obat tradisional terutama di negara Cina dan Asia Tenggara lainnya untuk menyembuhkan berbagai macam penyakit diantaranya sebagai obat antiinflamasi (antiradang), melancarkan sirkulasi darah, menghancurkan bekuan darah (fibrinolitik) dan lain sebagainya. Dalam tanaman ini terkandung berbagai macam zat berkhasiat seperti curcumin, curcuminoid, curdione, borneol, dan golongan senyawa flavonoid lainnya. Bagian tanaman yang dapat dimanfaatkan sebagai obat adalah rimpang dan daun (Ranjani et al,2012). Rimpang temu putih mengandung 1-2\% minyak menguap dengan komposisi utama sesquiterpene. Minyak menguap tersebut mengandung lebih dari 20 komponen zataktifseperti curzerenone (zedoarin) yang merupakan komponen terbesar, curzerene, pyrocurcuzerenone, curcumin, curcumemone, epicurcumenol, curcumol, isocurcumenol, procurcumenol, dehydrocurdione, furanodienone, isofuranodienone, furanodiene, zederone, dan curdione. Curcuminoid dan terpenoid memiliki efek sitotoksik dan antitumor.
Curcumin dapat mengaktivasi apoptosis pada sel, sedangkan sesquiterpen dan turunannya memiliki efek sitotoksik pada sel lain. Tepung (polisakarida) pada temu putih dapat menghambat pertumbuhan sel (Lakshmi et al,2011). Isocurcumenol memiliki efek langsung terhadap pengobatan antitumor berdasarkan penelitian yang telah dilakukan oleh beberapa ahli di India (Chitra et al, 2009).

\section{Bawang putih (Allium sativum L.)}

Bawang putih (A. sativum L.) merupakan salah satu sayuran umbi yang paling penting, yang digunakan sebagai agen bumbu dan bumbu untuk makanan. Selain itu juga, ia memiliki manfaat dalam menurunkan kolesterol plasma total, menurunkan tekanan darah dan penurunan agregasi trombosit. Bawang putih adalah spesies steril dan mereproduksi hanya dengan propagasi vegetative secara aseksual sehingga akan menampilkan keanekaragaman morfologi besar dalam bola, ukuran daun, warna, bentuk, kehadiran batang, tinggi, warna bunga, kesuburan dan bulbil (Topset) pengembangan (Ranjani et al,2012).

Bawang putih (A. sativum L.) merupakan keluarga Liliaceae dan genus Allium, yang berisi lebih dari 600 spesies. Hal ini menunjukkan bahwa bawang putih ditanam dan dikonsumsi antara 2780 dan 2100 SM. Ekstrak bawang putih telah 
digunakan sebagai obat tradisional untuk pencegahan dan pengobatan penyakit jantung (Lakshmi et al,2011). Bawang putih (Allium sativum) banyak digunakan selama berabad-abad untuk mengobati berbagai penyakit, diantaranya untuk mengurangi risiko terhadap tumor/kanker dan beberapa sanyawadidalamnya telah terbukti mengubah aktivitas karsinogenik sehingga menghambat pertumbuhan sel tumor dengan senyawa aktif didalamnya allicin (Chitraetal,2009).

\section{G. METODE DAN TAHAPAN PE- NELITIAN}

\section{Alat dan Bahan yang Diper- lukan}

Alat : alat gelas, lemari pendingin, laminator, mikropipet, timbangan analitik, vortex, mikroskop inventer, dan rak tabung.

Bahan : sel limfoma (raji) dari LPPT UGM, Media Komplit (RPMI, hepes, fungizon $0,5 \%$, penisilinstreptomisin $1 \%$, sodium bikarbonat, dan FBS 10\%), SDS 10\%, MTT 0,5\%, flask, temu putih, dan bawang putih.

\section{Tahapan Penelitian}

a. Determinasi tanaman

Tanaman temu putih dan bawang putih yang digunakan dalam penelitian terlebih dahulu dideterminasi untuk memastikan jenis spesies tanaman tersebut dengan bantuan buku Flora of Java. Determinasi dilakukan oleh peneliti di Laboratorium Biologi Farmasi
Universitas Islam Indonesia.

b. Penyiapan, pengeringan dan penyerbukan bahan baku temu putih (C. zedoaria) dan bawang putih ( $A$. sativum $\mathrm{L}$.)

Sebanyak $1 \mathrm{~kg}$ temu putih dan bawang putih didapat dari petani daerah kaliurang KM 20. Bahan baku segar tersebut dibilas dan disortir terhadap pengotor, kemudian diiris tipis dan dikeringkan dalam oven suhu $40^{\circ} \mathrm{C}$ selama 3 hari. Bahan baku simplisia yang telah kering kemudian disortir kembali dan dilanjutkan dengan proses pembuatan serbuk dengan suatu alat tanpa menyebabkan kerusakan atau kehilangan kandungan kimia yang dibutuhkan dan diayak hingga diperoleh serbuk dengan derajat kehalusan tertentu.

c. Pembuatan Ekstrak Etanol temu putih (C. zedoaria) dan bawang putih (A. sativum L.)

Pelarut yang digunakan adalah etanol $70 \%$. Satu bagian serbuk kering simplisia dimasukkan ke dalam maserator dan ditambahkan 10 bagian pelarut. Serbuk kering tersebut direndam selama 6 jam pertama sambil sekali-sekali diaduk, kemudian didiamkan selama $18 \mathrm{jam}$. Maserat dipisahkan dengan cara pengendapan, sentrifugasi, dekantasi atau filtrasi. Semua maserat dikumpulkan, kemudian diuapkan dengan penguap vakum atau penguap tekanan rendah 
hingga diperoleh ekstrak kental. Rendemen yang diperoleh berupa persentase bobot (b/b) antara bobot total ekstrak kental dengan bobot total serbuk simplisisa. Rendemen Ekstrak Etanol temu putih (C. zedoaria) tidak kurang dari $7,3 \%$ dan Ekstrak Etanol bawang putih ( $A$. sativum $\mathrm{L}$.) tidak kurang dari $26 \%$

d. Uji Organoleptik Simplisia dan ekstrak dari temu putih (C. zedoaria) dan bawang putih ( $A$. sativum L.)

Uji organoleptik dilakukan dengan mengamati tekstur simplisia, warna, bau, rasa, dan bentuk dari simplisia dan ekstrak dari temu putih (C. zedoaria) dan bawang putih ( $A$. sativum L.). Hasil yang diperoleh kemudian dibandingkan dengan organoleptik simplisia daun temu putih (C. zedoaria) dan bawang putih ( $A$. sativum L.) pada Farmakope Herbal Indonesia.

e. Pembiakan sel limfoma

Sel limfoma yang dibekukan pada suhu $-80^{\circ} \mathrm{C}$ dikeluarkan dari inkubator nitrogen dan dicairkan pada air suhu $37^{\circ} \mathrm{C}$. Disiapkan $10 \mathrm{ml}$ media RPMI 1640 dan dicampurkan sel limfoma yang telah mencair.Sel limfoma dan media RPMI 1640 yang telah tercampur disentrifuge dengan kecepatan 1500 rpm selama 5 menit. Supernatant dibuang dan pellet disuspensikan dalam media komplit sebanyak $10 \mathrm{ml}$, dan dipindahkan ke dalam flask. Kemudian disimpan dalam incubator $\mathrm{CO}_{2}$ dengan suhu $37^{\circ} \mathrm{C}$.

f. Penggantian media tiap 2- 3 hari dan dibagi kultur ketika sel mencapai $2-3 \times 10^{6} \mathrm{sel} / \mathrm{ml}$.

Sel kultur diamati dibawah mikroskop untuk melihat perkembangan selnya. Apabila sel sudah mencapai $2-3 \times 10^{6} \mathrm{sel} / \mathrm{ml}$, dilakukan pembagian sel dengan memindahkan $2 \mathrm{ml}$ suspensi sel ke dalam flask yang telah berisi media MK sebanyak $8 \mathrm{ml}$. Kemudian disimpan dalam incubator $\mathrm{CO}_{2}$ dengan suhu $37^{\circ} \mathrm{C}$.

g. Pemanenan sel

Jumlahnya diamati di bawah mikroskop apabila jumlahnya sudah cukup atau konfluen ( \pm $70 \%$ ). Diambil $10 \mu \mathrm{l}$ sel suspense kemudian dihitung menggunakan hemasitometer.

h. Uji antikanker

Uji sitotoksik menggunakan metode MTT assay. Sel dengan kepadatan 10.000-50.000 sel $/ \mathrm{ml}$ diambil sebanyak $100 \mu \mathrm{l}$, kemudian dimasukkan pada mikroplate (96 sumuran). Mikroplate diinkubasi selama 24 jam pada incubator $\mathrm{CO} 2$ dengan suhu $37^{\circ} \mathrm{C}$. Mikroplate yang telah diinkubasi ditambahkan sampel uji sebanyak $100 \mu$ l dengan masing-masing kadar yang ditentukan dan diinkubasi kembali selama 24 jam pada incubator 
C02. Setelah itu ditambahkan media komplit yang baru sebanyak $100 \mu \mathrm{l}$ dan ditambahkan $10 \mu \mathrm{l}$ MTT assay $0,5 \%$. Kemudian, diinkubasi selama 3 jam pada incubator $\mathrm{CO} 2$ dengan suhu $37^{\circ} \mathrm{C}$. Mikroplate yang telah diinkubasi ditambahkan SDS $10 \%$ dan diinkubasi kembali selama 24 jam pada suhu ruangan dan gelap. Pembacaan hasil dilakukan menggunakan Elisa reader pada panjang gelombang $550 \mathrm{~nm}$.

Data absorbansi yang diperoleh dihitung untuk melihat viabilitas sel dengan menggunakan rumus :
$\%$ Penghambatan $=$

$$
\frac{(A-D)-(B-C)}{(A-D)} \times 100 \%
$$

Keterangan : $\mathrm{A}=$ Absorbansi kontrol sel, $B=$ Absorbansi sampel, $\mathrm{C}=$ Absorbansi kontrol sampel, dan $\mathrm{D}=$ Absorbansi kontrol media

Nilai $I_{50}$ dihitung menggunakan regresi linear antara konsentrasi ekstrak dengan \% penghambatan.

\section{H. Rekapitulasi Rancangan dan Realisasi Biaya}

Tabel 1. Realisasi Biaya

\begin{tabular}{|r|l|l|l|c|}
\hline No. & Uraian & jumlah & $\begin{array}{l}\text { Hargasatuan } \\
(\mathrm{Rp})\end{array}$ & $\begin{array}{l}\text { Harga total } \\
(\mathrm{Rp})\end{array}$ \\
\hline 1. & Bawangputihsegar & $2 \mathrm{~kg}$ & 28.000 & 56.000 \\
\hline 2. & Temuputihsegar & $2 \mathrm{~kg}$ & 85.000 & 170.000 \\
\hline 3. & Pisau & 1 & 5.000 & 5.000 \\
\hline 4. & Alatpengirisbawang & 1 & 20.000 & 20.000 \\
\hline 5. & Alcohol 70\% & 2 liter & 45.000 & 90.000 \\
\hline 6. & Derigen 1 liter & 2 & 5000 & 10.000 \\
\hline 7. & Glove & 1 pak & 50.000 & 50.000 \\
\hline 8. & Mikroplate & 2 & 34.000 & 68.000 \\
\hline 9. & Flask 70 $\mu \mathrm{l}$ & $2 \mathrm{pak}$ & 120.000 & 240.000 \\
\hline 10. & Masker tali & 1 pak & 30.000 & 30.000 \\
\hline 11. & $\begin{array}{l}\text { Biaya lab awal di } \\
\text { Ipptugm }\end{array}$ & 2 orang & 510.000 & 1.020 .000 \\
\hline 12. & Determinasitanaman & 2 & 35.000 & 75.000 \\
\hline
\end{tabular}


Kombinasi Ekstrak .Istiqari, Kharismatul, Diny, Herianto.

\begin{tabular}{|r|l|l|l|c|}
\hline 13. & Media RPMI komplit & $1 \mathrm{~L}$ & 450.000 & 450.000 \\
\hline 14. & Aquabidest & $1 \mathrm{~L}$ & $\begin{array}{l}27.500 / \\
500 \mathrm{ml}\end{array}$ & 55.000 \\
\hline 15. & Sel line lymphoma & $\begin{array}{l}4 \mathrm{sel} \\
\text { biakan }\end{array}$ & 300.000 & 1200.000 \\
\hline 16. & Pipet tetes & 20 & 2500 & 50.000 \\
\hline 17. & Blue tip & 50 & 500 & 25.000 \\
\hline 18. & MTT & $5 \mathrm{mg}$ & 10.000 & 50.000 \\
\hline 19. & SDS & $10 \mathrm{~g}$ & 4000 & 40.000 \\
\hline & Total & & & 3.704 .000 \\
\hline
\end{tabular}

\section{HASIL DAN PEMBAHASAN}

1. Identifikasi tanaman dan uji organoleptik

\section{Determinasi tanaman}

Determinasi merupakan suatu cara untuk memastikan kebenaran suatu jenis spesies tanaman yang akan digunakan sebagai bahan obat dengan cara membandingkan ciri-ciri morfologi tanaman yang tertera pada buku pedoman dengan judul Floradan Flora of Java dengan bagian-bagian yang terdapat dalam tanaman.

a. Kunci determinasi bawang putih $(A$. sativum $\mathrm{L}$.)

$1 b-2 b-3 b-4 b-12 b-13 b-14 b-$

$17 b-18 b-19 b-20 b-21 b-22 b-$ $23 b-24 b-25 b-26 b-27 b-799 b-$ 800b-801b-802b-803b-804b$804 b-805 e-806 b-807 a-$ $808 c-809 b-810 b-811 a-812 b-$ $815 b-816 b-818 b-820 b-821 b-$ $822 a-823 c-825 b-826 b-829 b-$
$830 b-831 b-832 b-833 b-834 a-$ 835a-836a-837e-851a-852b$853 b-854 a-855 c-856 b-857 a-$ $858 a-859 c-860 b-872 b-874 b-$ 875b-876b-877a-878a-879b880b-881a- family : liliaceae dan genus : Allium sativum $\mathrm{L}$.

b. Kunci determinasi temu putih (C. zedoaria) yaitu :

$1 b-2 b-3 b-4 b-6 b-7 b-9 b-10 b-$ 11a-gol 5

67b-69b-70b-71a(32)-family: Zingiberaceae

1a-2b-6b-7a-genus: curcuma, spesies : Curcuma zedoaria Roxb

Kunci determinasi tersebut menunjukkan bahwa bawang putih dan temu putih memiliki ciri-ciri morfologi sesuai dengan yang tercantum pada Farmakope Herbal Indonesia.

\section{Uji Organoleptik}

Uji organoleptik dilakukan sebagai pengenalan yang 
sederhana dan subjektif dengan mendeskripsikan bentuk, warna, bau dan rasa menggunakan panca indera. Uji organoleptik simplisia dan ekstrak dari temu putih ( $C$. zedoaria) dan bawang putih ( $A$. sativum L.) dibandingkan dengan organoleptik simplisia dan ekstrak pada Farmakope Herbal Indonesia. Hasil uji organoleptik simplisia dan ekstrak Tabel I. temu putih (C. zedoaria) dan pada tabel II. bawang putih $(A$. sativum L.) menunjukkan bahwa bahan yang digunakan dalam penelitian memiliki organoleptik yang sama dengan organoleptik pada Farmakope Herbal Indonesia.

Tabel I. Hasil uji organoleptik temu putih (C. zedoaria)

\begin{tabular}{|l|l|l|l|l|}
\hline Parameter & $\begin{array}{l}\text { Simplisia temu } \\
\text { putih yang } \\
\text { digunakan }\end{array}$ & $\begin{array}{l}\text { Simplisia temu } \\
\text { putih pada } \\
\text { Farmakope } \\
\text { Herbal Indonesia }\end{array}$ & $\begin{array}{l}\text { Ekstrak } \\
\text { etanol temu } \\
\text { putih yang } \\
\text { digunakan }\end{array}$ & $\begin{array}{l}\text { Ekstrak etanol } \\
\text { temu putih pada } \\
\text { Farmakope } \\
\text { Herbal Indonesia }\end{array}$ \\
\hline Bau & Tidakberbau & Tidak berbau & Khas & Khas \\
\hline Rasa & Pahit & Agak pahit & Pahit & Pahit \\
\hline Bentuk & $\begin{array}{l}\text { Kepingan pipih, } \\
\text { ringan, bentuk } \\
\text { bundar hingga } \\
\text { jorong atau } \\
\text { berbentuk tidak } \\
\text { beraturan, } \\
\text { tebalnya 2-5 } \\
\text { mm. }\end{array}$ & $\begin{array}{l}\text { Kepingan pipih, } \\
\text { ringan, bentuk } \\
\text { bundar hingga } \\
\text { jorong atau } \\
\text { berbentuk tidak } \\
\text { beraturan, } \\
\text { tebalnya 2-5 mm. }\end{array}$ & Kental & Kental \\
\hline Warna & $\begin{array}{l}\text { Kuning muda } \\
\text { kecoklatan }\end{array}$ & $\begin{array}{l}\text { Kuning muda } \\
\text { hingga kuning } \\
\text { muda kecoklatan }\end{array}$ & Coklat & Coklat \\
\hline
\end{tabular}

Tabel II. Hasil uji organoleptikbawang putih (A. sativum L.)

\begin{tabular}{|l|l|l|l|l|}
\hline Parameter & $\begin{array}{l}\text { Simplisia } \\
\text { bawang } \\
\text { putih yang } \\
\text { digunakan }\end{array}$ & $\begin{array}{l}\text { Simplisia } \\
\text { bawang putih } \\
\text { pada } \\
\text { Farmakope } \\
\text { Herbal } \\
\text { Indonesia. }\end{array}$ & $\begin{array}{l}\text { Ekstrak } \\
\text { etanol } \\
\text { bawang putih } \\
\text { yang } \\
\text { digunakan }\end{array}$ & $\begin{array}{l}\text { Ekstrak etanol } \\
\text { bawang putih } \\
\text { pada } \\
\text { Farmakope } \\
\text { Herbal } \\
\text { Indonesia. }\end{array}$ \\
\hline Bau & $\begin{array}{l}\text { Khas } \\
\text { aroma } \\
\text { bawang }\end{array}$ & $\begin{array}{l}\text { Khas aromatis } \\
\text { menyengat }\end{array}$ & $\begin{array}{l}\text { Khas aroma } \\
\text { bawang }\end{array}$ & $\begin{array}{l}\text { Khas aromatis } \\
\text { menyengat }\end{array}$ \\
\hline Rasa & Pedas & Pedas & Pedas & $\begin{array}{l}\text { Pedas agak } \\
\text { kejat }\end{array}$ \\
\hline Bentuk & Pipih & Pipih & $\begin{array}{l}\text { Kental } \\
\text { seperti } \\
\text { caramel }\end{array}$ & Kental \\
\hline Warna & $\begin{array}{l}\text { Kuning } \\
\text { muda }\end{array}$ & Kuning muda & $\begin{array}{l}\text { Merah } \\
\text { kecoklatan }\end{array}$ & Coklat \\
\hline
\end{tabular}


2. Pembuatan Ekstrak Etanol temu putih (Curcuma zedoaria) dan bawang putih (Allium sativum $\mathrm{L}$.)

Proses ekstraksi rimpang temu putih (C. zedoaria) dan bawang putih (A. sativum L.) dilakukan dengan metode maserasi menggunakan pelarut etanol (1:10) dengan cara melarutkan 100 gram serbuk kedalam 1 liter pelarut etanol $70 \%$. Hasil maserasi dari 100 gram rimpang temu putih (C. Zedoaria) diperoleh bobot total ekstrak sebesar 8,34 gram sehingga rendemen ekstrak temu putih yaitu 8,34\%. Farmakope Herbal Indonesia menyatakan bahwa rendemen ekstrak kental rimpang temu putih yaitu tidak kurang dari $7,3 \%$. Hasil maserasi dari 100 gram bawang putih ( $A$. sativum L.) diperoleh bobot total ekstrak sebesar 27,79 gram sehingga rendemen ekstrak bawang putih ( $A$. sativumL.) yaitu $27,8 \%$. Farmakope Herbal Indonesia menyatakan bahwa rendemen ekstrak kental bawang putih yaitu tidak kurang dari $26 \%$. Hal ini menunjukkan bahwa rendemen yang dihasilkan sudah memenuhi persyaratan yang ada. Perhitungan rendemen ini bertujuan untuk mengetahui seberapa banyak kehilangan berat dari serbuk simplisia yang digunakan.

\section{Uji aktivitas sel limfoma dengan metode MTT assay}

Uji 3-(4,5-dimetiltiazol-2yl)-2,5difeniltetrazolium bromida (MTT) adalah uji yang sensitif, kuantitatif dan terpercaya. Reaksi MTT merupakan reaksi reduksi selular yang didasarkan pada pemecahan garam tetrazolium MTT berwarna kuning menjadi kristal formazan berwarna biru keunguan. Metode perubahan warna tersebut digunakan untuk mendeteksi adanya proliferasi sel. Sel yang mengalami proliferasi, mitokondria akan menyerap MTT sehingga selsel tersebut akan berwarna ungu akibat terbentuknya kristal tetrazolium (formazan) (Depamede dkk 2009 : 97). Prinsip uji MTT adalah mengukur aktivitas selular berdasarkan kemampuan enzim mitokondria reduktase pada mitokondria dalam mereduksi garam Metiltiazol Tetrazolium (MTT). Ketika bermetabolisme, sel-sel hidup akan menghasilkan enzim mitokondria reduktase. Enzim ini bereaksi dengan MTT dan membentuk kristal formazan berwarna ungu. Intensitas warna ungu yang terbentuk proporsional dengan jumlah sel hidup, sehingga jika intensitas warna ungu semakin besar, maka jumlah sel hidup semakin banyak (Amalina 2008 :16).

Ekstrak kombinasi temu putih dan bawang putih diujikan pada sel lympoma dengan seri dosis 50 : 50 ( $500: 500 ; 250: 250 ; 125$ : 
$125 ; 62,5: 62,5 ; 31,25: 31,25$; 15,$625 ; 15,625$ ppm). Hasil dari pengujian didapatkan data nilai absorbansi untuk masing-masing dosis. Nilai absorbansi digunakan untuk menghitung besarnya persen (\%) kematian sel. Parameter yang diukur adalah besarnya persen kematian sel (\%) dan kristal formazan yang terbentuk.

Tabel III. Hasil Uji MTT dari ekstrak kombinasi temu putih dan bawang putih $(50: 50)$

\begin{tabular}{|c|c|c|c|}
\hline Dosis (ppm) & $\begin{array}{l}\text { Absorbansi } \\
\text { perlakuan } \\
\text { sampel }\end{array}$ & $\begin{array}{l}\text { Absorbansi } \\
\text { kontrol } \\
\text { sampel }\end{array}$ & $\begin{array}{l}\text { Kematian sel } \\
(\%)\end{array}$ \\
\hline $500: 500$ & 0,553 & 0,710 & 100 \\
\hline $250: 250$ & 1,105 & 0,787 & 50,9 \\
\hline $125: 125$ & 1,138 & 0,749 & 40 \\
\hline $62,5: 62,5$ & 1,126 & 0,637 & 24,7 \\
\hline $31,25: 31,25$ & 1,330 & 0,489 & 0 \\
\hline $15,625: 15,625$ & 1,086 & 0,486 & 7,6 \\
\hline \multicolumn{2}{|c|}{ Rata-rata kontrol sel } & 1,137 & \\
\hline \multicolumn{2}{|c|}{ Rata-rata kontrol media } & 0,488 & \\
\hline \multicolumn{2}{|l|}{$I \mathrm{C}_{50}$} & 463,27 ppm & \\
\hline
\end{tabular}

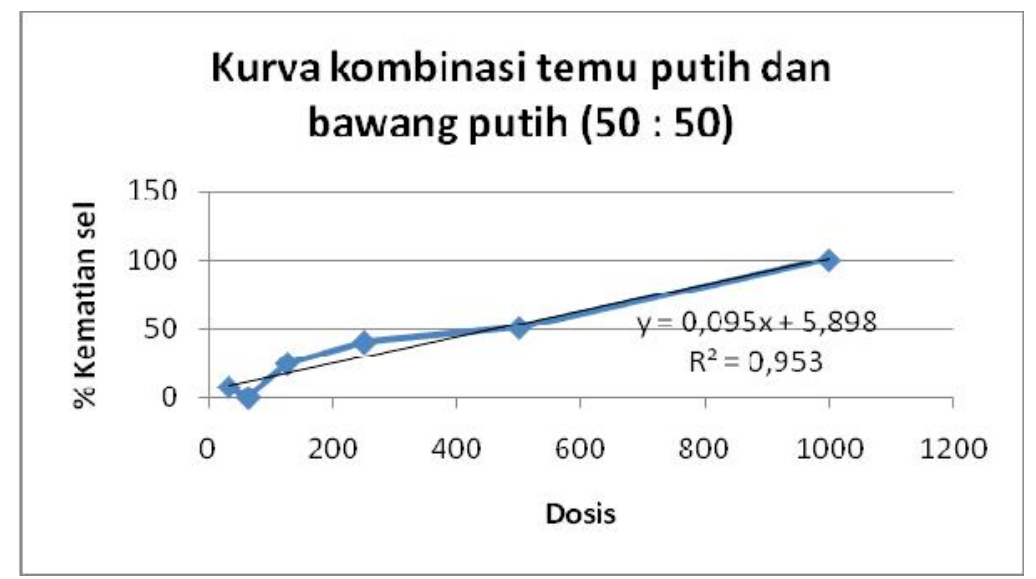

Gambar 1. Kurva Kombinasi temu putih dan bawang putih (50:50)

Berdasarkan Tabel III dan gambar 1, semakin tinggi konsentrasi dosis kombinasi ekstrak temu putih dan bawang putih, maka semakin tinggi persentase kematian sel limfoma sehingga kombinasi temu putih dan bawang putih dapat digunakan sebagai anti tumor limfoma. Sel yang mati terlihat adanya sel yang lisis dan tidak bercahaya. Selain itu kristal formazan yang berbentuk sangat sedikit. Hal ini mengindikasikan bahwa 
kombinasi ekstrak temu putih dan toksik. Suatu ekstrak dianggap toksik bawang putih mampu menghambat terhadap sel kanker jika memiliki nilai atau menurunkan aktivitas sel limfoma $I_{50}$ kurang dari 1000 ppm (Amalina karena terlihat banyak sel limfoma 2008 :16). Berdasarkan hal tersebut yang mati. Nilai $I_{50}$ menunjukkan maka ekstrak kombinasi ekstrak nilai konsentrasi yang menghasilkan temu putih dan bawang putih dengan kematian sel $50 \%$ dan menunjukkan nilai sebesar 463,27 ppm tergolong potensi ketoksikan suatu senyawa ekstrak yang bersifat toksik terhadap terhadap sel. Semakin besar nilai $I_{50}$ sel limfoma.

maka senyawa tersebut semakin tidak

Tabel IV. Hasil Uji MTT dari ekstrak kombinasi temu putih dan bawang putih (75:25)

\begin{tabular}{|c|c|c|c|}
\hline Dosis (ppm) & $\begin{array}{l}\text { Absorbansi } \\
\text { perlakuan } \\
\text { sampel }\end{array}$ & $\begin{array}{l}\text { Absorbansi } \\
\text { kontrol } \\
\text { sampel }\end{array}$ & $\begin{array}{l}\text { Kematian sel } \\
(\%)\end{array}$ \\
\hline $750: 250$ & 0,497 & 0,704 & 100 \\
\hline $375: 125$ & 0,764 & 0,691 & 88,72 \\
\hline $187,5: 62,5$ & 1,163 & 0,607 & 14,3 \\
\hline $93,75: 31,25$ & 1,100 & 0,509 & 8,82 \\
\hline $46,875: 15,625$ & 1,152 & 0,541 & 5,87 \\
\hline $23,4375: 7,8125$ & 1,155 & 0,530 & 3,64 \\
\hline $11,71875: 3,90625$ & 1,179 & 0,493 & 0 \\
\hline \multicolumn{2}{|l|}{ Rata-rata kontrol sel } & 1,137 & \\
\hline \multicolumn{2}{|c|}{ Rata-rata kontrol media } & 0,488 & \\
\hline \multicolumn{2}{|l|}{$\mathrm{IC}_{50}$} & 449,04 ppm & \\
\hline
\end{tabular}

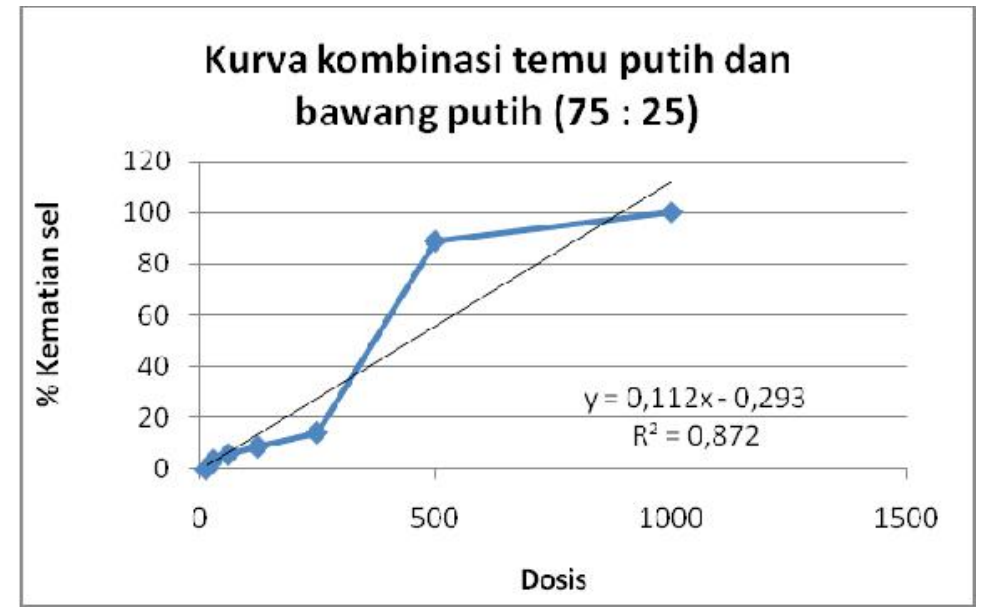

Gambar 2. Kurva Kombinasi temu putih dan bawang putih (75:25) 
Berdasarkan Tabel IV dan gambar 2, semakin tinggi konsentrasi dosis kombinasi ekstrak temu putih dan bawang putih, maka semakin tinggi persentase kematian sel limfoma. Hal ini sudah dijelaskan seperti tabel dan kurva diatas. Nilai $I C_{50}$ menunjukkan nilai konsentrasi yang menghasilkan kematian sel $50 \%$ dan menunjukkan potensi ketoksikan suatu senyawa terhadap sel. Semakin besar nilai $I_{50}$ maka senyawa tersebut semakin tidak toksik. Suatu ekstrak dianggap toksik terhadap sel kanker jika memiliki nilai $I_{50}$ kurang dari 1000 ppm (Amalina 2008 :16). Berdasarkan hal tersebut maka ekstrak kombinasi ekstrak temu putih dan bawang putih dengan nilai sebesar 449,04 ppm tergolong ekstrak yang bersifat toksik terhadap sel limfoma.

\section{K. DAFTAR PUSTAKA}

Anonim. 2009. Farmakope Herbal Indonesia Edisi I. Jakarta: DepartemenKesehatan RI. HIm163-171.

Arulappa R.X, llango K. 2013. Anticancer Activity of Extracts of Aerial Parts of Tephrosia Spinosa (L.F) Pers. Research and Reviews: Journal of Pharmacy and Pharmaceutical Sciences 2 (2): 59-64.
Chitra V, Shrinivas S, Nandu K. 2009. Evaluation of Anticancer Activity of Vitex Negudo In Experimental Animals: An In Vitro \& In Vivo Study. International Journal of Pharmatech Research 1 (4): 1485-1489.

Harahapy, Kesumahati, Lelly W. 2008. Uji sitotoksisitas ekstrak kering rimpang temu putih terhadap sel caski secara in vitro.Jurnal Bahan Alam Indonesia 6 (4): 135-138.

Kintzios S E, Barberaki M G. 2004. Plants and Cancer in Plants that Fight Cancer. Editor: Spiridon E. Kintziosdan Maria G Barberaki, Florida,AS: CRC Press LLC.

Lakshmi S, Padmaja G, Remani P. Antitumour Effects of Isocurcumenol Isolatedfrom Curcuma zedoaria Rhizomes on Human and Murine Cancer Cells. International Journal of Medicinal Chemistry : 1-13.

National Cancer Institut at The National Institut Of Health, What You Need ToKnow AboutTMCancer, National Cancer Institut, Available at:http://www.cancer. gov/cancertopics/wyntk/cancer/ page2. Terakhir diupdate tanggal 04 Oktober 2006, Diakses tanggal 23 juni 2013 jam 21:09

Putra S. 2010. Efek Pemberian Ekstrak Etanol Rimpang Temu Putih (Curcuma zedoria) terhadap Gambaran Klinis 
Kelinci (Oryctolagus cuniculus) pada Proses Pembentukan Tumor Mammary yang Diinduksi dengan Metil-N-Nitrosourea. SKRIPSI. Fakultas Kedokteran Hewan Institut Pertanian Bogor: 22-25.

Ranjani R, Ayya Raju. 2012. Anticancer Properties of Allium sativum-A Review. Asian Journal of Biochemical and Pharmaceutical Research 3 (2): 19

Depamede, S.N., dan Rosyidi, A. 2009. Penghambatan proliferasi limfosit mencit Balb/C oleh ekstrak testis sapi bali : Peran TGF- $\beta$. Media Peternaka 32 (2) : 95-103.

Amalina, N. 2008. Uji sitotoksik ekstrak etanol $70 \%$ buah merica hitam (Piper nigrum L.) terhadap sel Hela. Fakultas Farmasi Universitas Muhammadiyah Surakarta. Surakarta : 1-17.

\section{LAMPIRAN ALAT DAN BAHAN}

a. Bawang Putih

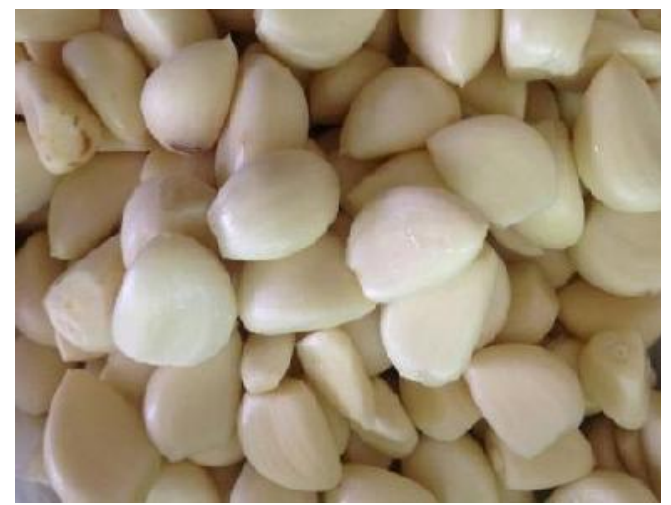

b. Rotary evaporator

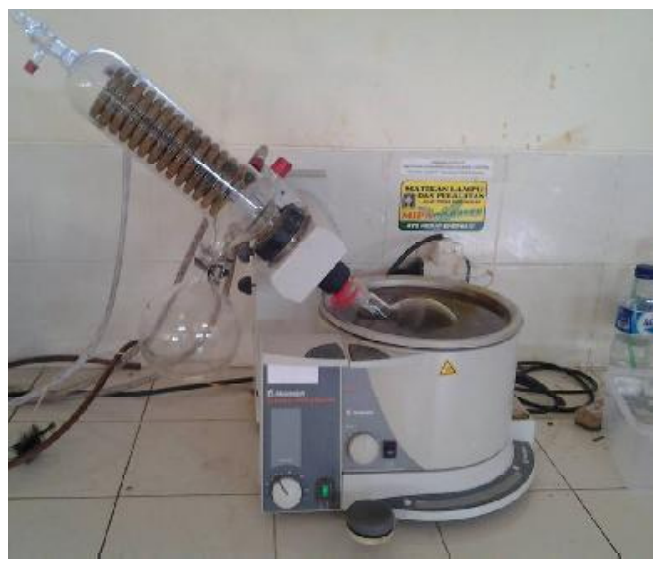

c. Serbuk temu putih (C1) dan bawang putih (C2)

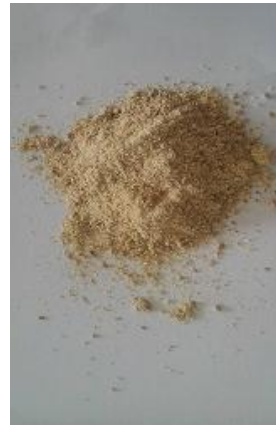

C1

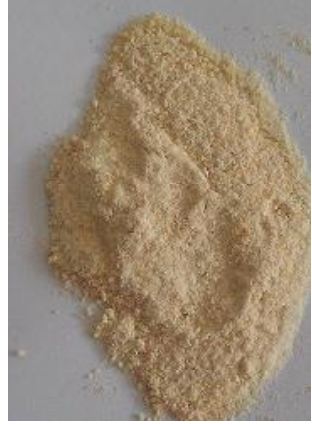

C2 d. Ekstrak Kental Temu putih (D1) dan bawang putih (D2)

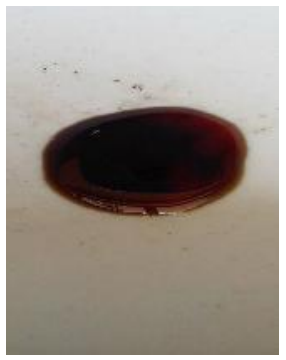

D1

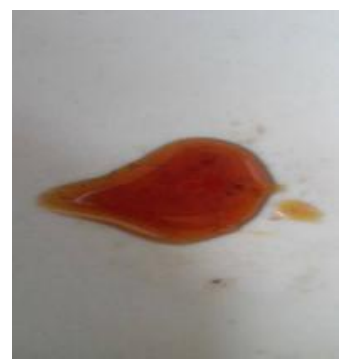

D2 e. Proses pembiakan media didalam LAF (laminar air flow) 
KHAZANAH, Vol. 7 No.2 Januari 2015

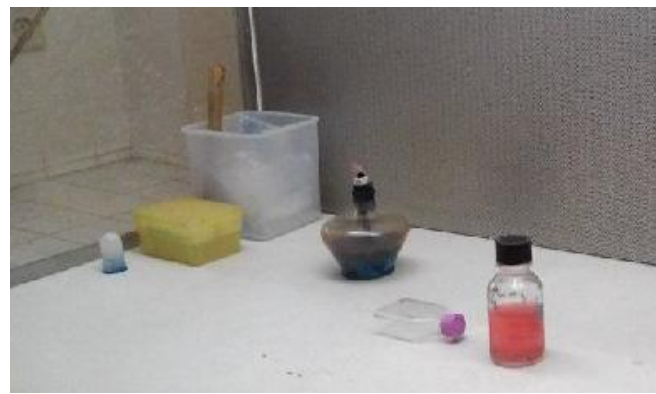

h. Uji aktivitas

f. Sel yang dibiakkan dalam media flask
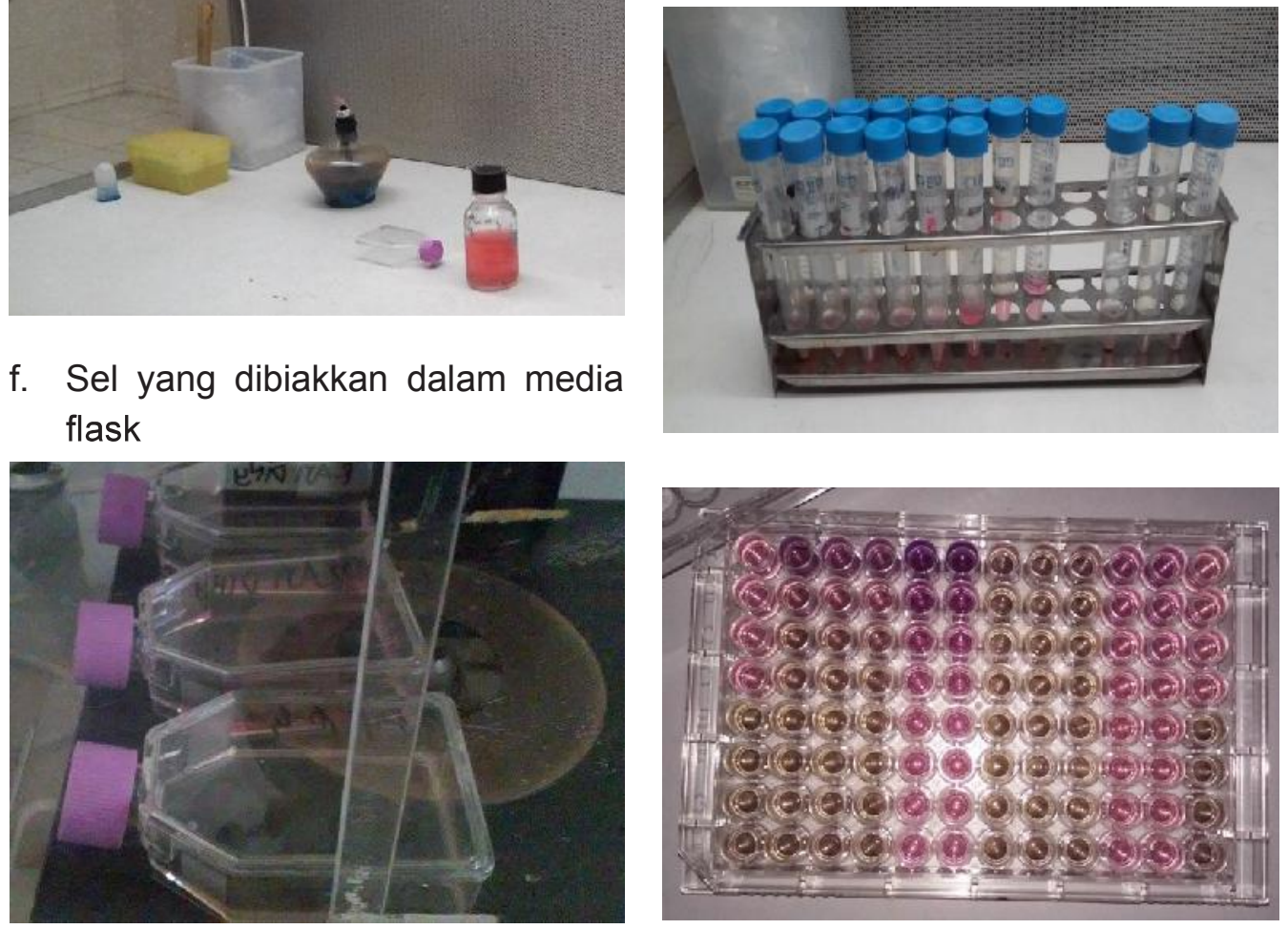

g. Sel yang hidup
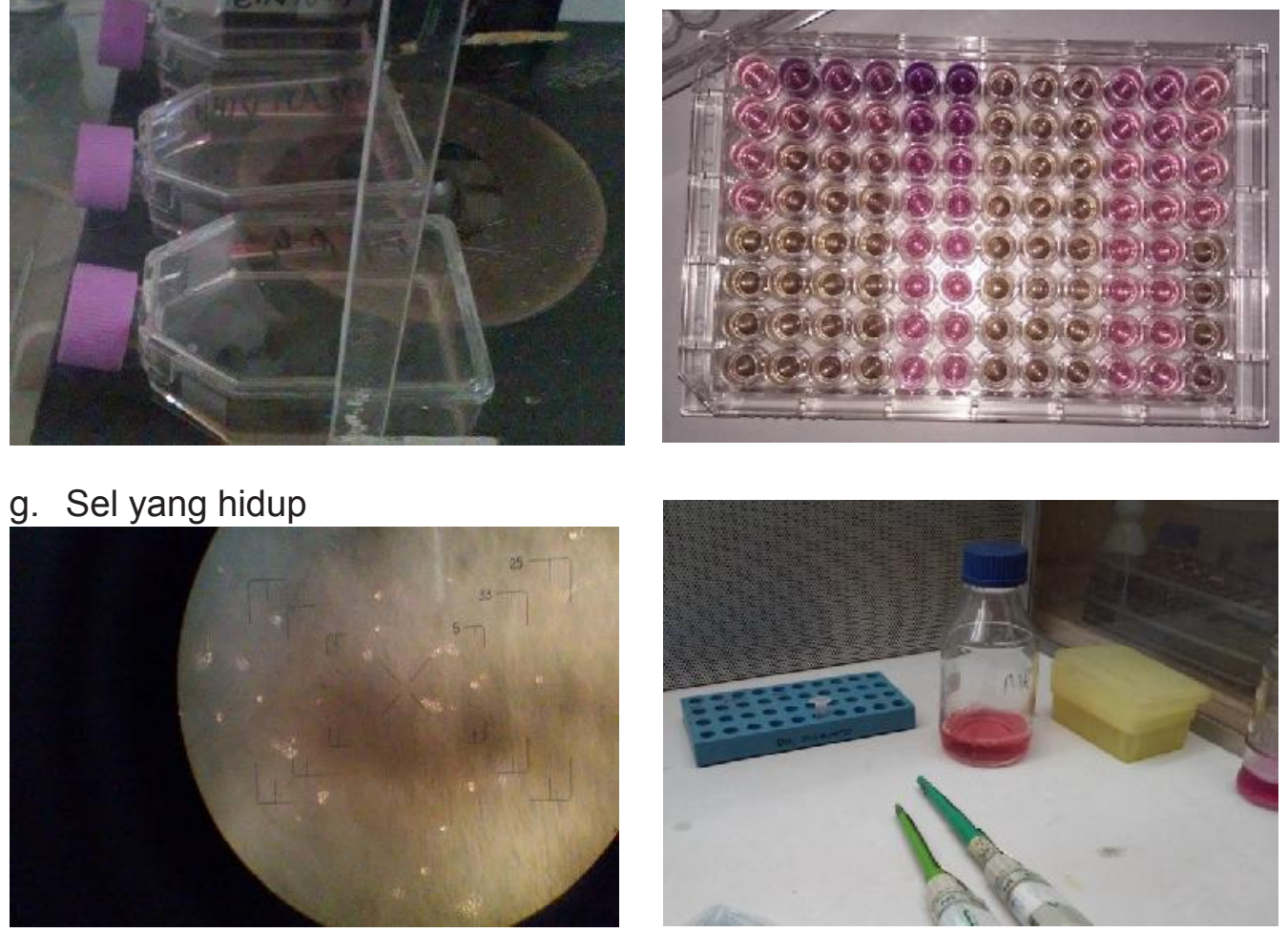